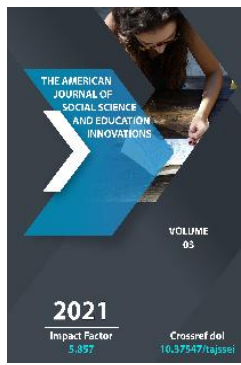

Journal Website: http://theamericanjour nals.com/index.php/taj ssei

Copyright: Original content from this work may be used under the terms of the creative commons attributes 4.0 licence.

\section{The Contribution Of Uzbek Women To The Victory In Second} World War

\section{Dilfuza Tukhtasinovna Sobirova}

Associate Professor At The Department History Of Uzbekistan Of Andizhan State University, Candidate Of Historical Sciences, Andizhan Region, Republic Of Uzbekistan

Farkhod Khasan Ugli Abdullaev

Master At The Department History Of Uzbekistan Of Andizhan State University, Andizhan Region, Republic Of Uzbekistan

\title{
ABSTRACT
}

The article tells the story of the selfless work of Uzbek women during the Second World War, their contribution to the great victory on the basis of new facts. Besides, it shown that the unscientific conclusion that "women's issues were solved" in the former Soviet Union led the Soviet government and the Communist Party to involve women in social production under the slogan of "economic liberation"

\section{KEYWORDS}

Women, center, economy, politics, world war, communist party, bolshevik, proletarian.

\section{INTRODUCTION}

It is known that during the former Soviet Union, the central government formed Uzbekistan as an economic colony, a base for the supply of cheap raw materials for the "center". The unscientific conclusion that "women's issues were solved" in the former
Soviet Union led the Soviet government and the Communist Party to involve women in social production under the slogan of "economic liberation" and to make them the main productive force in society by using their labor as cheap labor "made it possible". 


\section{METHODS}

Widespread involvement of local women in production was necessary, first of all, to strengthen the economic base of the dictatorial regime. First of all, the main goal of socialism was to develop its economy, and for this purpose it used women as a labor force and involved them in social production. "In no country in the world except the socialist countries has the percentage of working women been so high"[1.38]. No one was interested in the natural subtlety of the female body, its inability to perform heavy physical labor, and the serious social consequences if this balance was disturbed. This was because the dictatorial regime was interested in their participation in production more than the family, emphasizing that their full freedom could not be ensured without the mass participation of women in production. Therefore, it was considered that "Economic independence is a key achievement in ensuring women's equality in society", "the main task in ensuring economic independence is to involve women in social work" [2.22].

\section{RESULTS AND DISCUSSIONS}

In the resolution of the Central Committee of the Communist Party of Uzbekistan (b) of May 20, 1938 on "O rabote sredi jenshchin" (Work among women) [3.245] to involve women in industrial production by improving their skills, improving their living conditions, focused on recruitment to leadership positions. Women of the Republic were routinely mobilized to implement similar decisions taken by the party and the government.

The resolution of the Central Committee of the Bolshevik Communist Party of Uzbekistan in June 1940 "On measures to involve women in the system of consumer cooperation in Uzbekistan" ("On measures to involve women in the system of consumer cooperation in Uzbekistan") [3.245] The primary task was to increase their share in the total number of workers in consumer cooperatives to at least $35 \%$ by involving at least 10,000 women, primarily indigenous women, in social production [3.245].

In December 1940, the number of women employed in the republican consumer cooperative reached 8,863 , of whom 3,135 were indigenous women. Also, 482 women working in this field were communist women and 1208 were Komsomol girls [3.245]. The aim of the wider involvement of communist and Komsomol women in social production was to realize the Communist Party's political interests among women [4.109].

Based on the decision of the Central Committee of the Bolshevik Communist Party of Uzbekistan of June 9, 1940, the Council of the Komsomol Youth Union of Uzbekistan ("On measures to involve women in the system of consumer cooperation in Uzbekistan") made a special decision to enroll in training courses [4.246]. In order to ensure the implementation of the decision, after completing one-month courses, 1,500 Komsomol women were sent to districts and villages - 225 to Tashkent region, 227 to Samarkand region, 525 to Ferghana region, 300 to Bukhara region, 105 to Khorezm region [3.246]. Thus, the large number of demanded workers in the economic economy, which played an important role in the construction of socialism, was filled at the expense of the women of the local nation. During the war against Nazi Germany, which began on June 22, 1941, the participation and share of Uzbek women in the national economy reached a very high level. They took an active part in all spheres of the national economy and also worked at the expense of the men who went to the front. 
Thousands of women left behind at the front shouted "Everything for the front!", "All mothers for the defense of the Motherland!", "Behind the front as in the front!", "Only forward and forward!" they showed courage in labor with high responsibility in response to their slogans. Since the second day of the war, thousands of people have rallied in all enterprises, mahallas and other public places in Tashkent, expressing their readiness to defend the Motherland, whether on the battlefield, at work or anywhere.

On June 26, 1941, a rally of thousands of people took place at the Tashkent Textile Mill, during which they stated that they had accepted the increased obligations. In the city, "Work for yourself and your comrade who went to the front!". The slogan spread widely. On July 4, the women of the Oktyabr district of Tashkent took part in the "Take the place of men in any situation!"."Towards the machine on the labor front!" At the rally of 15 thousand people, an appeal was made to the women of the republic. It read: "... Dear sisters! Let's take the place of our husbands, brothers, sisters and sons next to the machine, behind the wheel of the combine and in the field. "In particular, the call of housewife Aysha Yusupova that we will contribute to the victory on the front behind the front called on many women to provide the defense of the Motherland with their labor. Following these appeals and invitations, the women of the capital began to apply to the city party committee and state bodies for sending and employment to the front. On June 22-26 alone, 1,551 women across the city applied to be sent to the front, and on July 115, 7,508 women applied for employment in the October district [7.8]. In July 1941, the newspaper Pravda published an appeal to "all women of the USSR" [8.39]. The essence of the appeal was to mobilize women to work behind the front lines, taking the place of men. After that, the movement to train women in the "men's profession" in enterprises and organizations of the republic gained momentum.

As a result of the initiative of the workers of the plant "Kolkhozchi" in Samarkand to train women to work directly in front of the machine, 35 housewives became lathe operators and locksmiths [8.40]. Thus, the proportion of women in the manufacturing enterprises of the republic has been increasing year by year. If this was 34 percent in 1940, it was 50 percent in 1942 and 63 percent in 1943 [8.41].

On July 3, 1941, at a rally of thousands of Bukhara workers, women were also called to take the place of men. 100 of the women of Kagan Railway, who were the first to join the call, took the place of men in a short period of time and played a major role in the smooth continuation of the railway service. The ranks of station attendants, female machinists have expanded. By the end of 1941, more than 5,000 women in the province had owned men's looms. By 1943, 82 percent of the industrial workers in the province were women [9,331].

Thus, 1- and 6-month short-term training courses for industry and agriculture, 10-day seminars, and schools for women were organized at technical colleges and MTS for the training of women in mass professions. As a result, 103,000 women workers were trained during the three years of the war [10.45]. They were involved in production that required heavy physical labor. In particular, 1,700 Uzbek women were employed at the Angren coal mine $[10,246]$.

In particular, the decree of the Presidium of the Supreme Soviet of the USSR of February 
13, 1942 further expanded the ranks of workers at the expense of able-bodied women, adolescents and pensioners [11.226].

Mass mobilization of women to study men's professions has begun in the country. In October 1941, 52.6\% of the 2,624 workers at the Tashselmash plant in Tashkent were women, while in November, 7,620 women were trained as men at 42 industrial enterprises in Tashkent. If in 1940 the share of women employed in the republic's industry was 34 per cent, due to the compulsory policy pursued by the Soviet government and the Communist Party, women accounted for 54.9 per cent by 1942 [11.226]. industrial enterprises accounted for 63.5 percent of the labor force $[3,268]$ and played a crucial role in the national economy.

On October 15, 1941, 11,000 workers were employed at 42 industrial enterprises in Tashkent, 8,000 of whom were women [12.7]. Uzbek women activists such as J. Obidova and F. Yuldashbaeva have been actively involved in organizing women's employment in industrial enterprises.

However, the center was not satisfied with the fact that the number of indigenous women was "a minority" among those trained for industrial production. Therefore, based on the Decree of the Presidium of the Supreme Soviet of the USSR of February 13, 1942, the X Plenum of the Central Committee of the CPSU (b) on March 6, 1944, the X Plenum of the Central Committee of the CPSU came out. Following these measures, in early 1945 , more than 4,000 Uzbek women began working in manufacturing enterprises in Tashkent [10.10]. Of the 308 enterprises evacuated from the center to Central Asia during the war, 104 went to Uzbekistan; 55 of them were located in Tashkent and Tashkent region [10.10]. One of the 55 industrial enterprises relocated to
Tashkent is the Chkalov Aviation Plant, which has been relocated near Moscow, and within three months, due to great organizational work, the plant has been staffed and started operating at full capacity. Seventy percent of the total number of workers were new hires, 362 of whom were Uzbek women [11.38]. The shortage of personnel, which arose as a result of the departure of experienced workers to the front, was filled in a very short period of time by the training and education of newcomers, inexperienced and unskilled workers, in various production occupations.

After the decision of the Bureau of the Central Committee of the Communist Party of Uzbekistan in September 1941 to transfer the city's industrial enterprises to the production of weapons, in 1942, 64 of the 137 enterprises in the city switched to military production [3.7]. Further growth of military production was associated with the introduction of new technologies, increasing labor productivity and overcoming enormous challenges. The administrative-command management of the economy by the state bodies reached its peak, especially during the war years. The main task set by the authorities was to work to the fullest, no matter how much the physical and mental energy of the people was spent, without taking into account the available opportunities, and to carry out the plan. The heavy workload fell mainly on women and young people.

As a result of pressure and oppression based on the Soviet method of command-andcontrol, women were forced to adapt to the existing environment. They unknowingly aspired to be the bulwarks of the socialist economy.

Even during the war years, efforts to empower women in production continued through the organization of competitions. In 
particular, Idrisova, an employee of the Tashkent Textile Combine, exceeded the plan and managed to gin 1 ton of cotton a month. M. Nosirova, a weaver, worked with 80 looms at a time, exceeding the plan [5.109], and A.Shumilova, an employee of the Andijan factory named after Volodarsky, managed to fulfill the daily norm by 3 and 3.5 times more [13.23]. On May 30, 1942, A.Buyanchina, an employee of the Andijan Engine Repair Plant, called on his colleagues to increase production efficiency, increasing the daily norm by 230$250 \%$. Workers of the Andijan plant "Stroymashina" also took the initiative to exceed the daily norm by 2-3 times [14.8].

At the Toshselmash plant G. Khalilova, $\mathrm{H}$. Sharipova, Reshetnikova, Pushkareva from Toshtram, sisters Marufa, Mahnusa Gafurova from the Bolshevik artel, Muhabbat Nosirova, Azamova and others from the Textile Combine fulfilled their daily norms by 200\%. 1233 women worked in the men's profession. At the Toshselmash plant alone, 230 women worked in the ammunition plant. Established in June 1945 by the Presidium of the Supreme Soviet of the USSR for the workers of the front, "For valiant labor during the Great Patriotic War. Representatives of women of Tashkent were also awarded the medal 19411945" [14.7].

\section{CONCLUSION}

Through such incentives, competitions that were artificially politically motivated led to the oppression of women under hard labor. In fact, competitions were just a form of forcing workers to work harder for the state. Since the participation of women workers in the competition was an assessment of their political consciousness, the women workers were forced to work overtime, to win the competition, without any privilege. Competitions were an important factor in the artificial acceleration of the realization of the Soviet goal by local women, and were an expression of the Soviet pursuit of quantitative indicators in accordance with the logic of "revolutionary-bureaucratic" thinking. So in the years of World War II, in earlier times, the hard work was on women. Uzbek women have worked tirelessly in industry and agriculture, making a worthy contribution to the victory over fascism.

\section{REFERENCES}

1. Akhtyamova Yu.S. Women's issues: two worlds, two different approaches. $-\mathrm{T}$ : Bilim.1987. p.6.

2. Alimova D.A. The solution of the women's issue in Uzbekistan (1917-1941).- T: Fan. 1987.p.45.

3. Aminova R.Kh. October and the solution of the women's issue in Uzbekistan. $-\mathrm{T}$ : Fan. 1975 p. 245.

4. Bobojonova D.B. Socio-economic relations in Uzbekistan.-T: Shark.1999.p.109.

5. The history of the working class in Uzbekistan. Volume.III. -T .: Fan. 1966, p. 38.

6. History of the Uzbek USSR, vol. III, Tashkent, Publishing house "Fan" of the Uzbek SSR, 1967. vol. IV, p. 109.

7. Salomov Ismail. Big test winners.//Saodat. 1985.№5.p.8.

8. Sulaymonova Kh. Women in Uzbekistan are active participants in communist construction. Publishing house of the Academy of Sciences of the USSR. 1955. p.39.

9. Sirojev O. The role of the people of Bukhara in the victory over fascism. The historical contribution of Uzbekistan to the victory over fascism 1941-1945. Proceedings of the scientific-theoretical conference.-T .: Science. 1996.p.331. 
10. New history of Uzbekistan. Uzbekistan during the Soviet colonial period. Book 2. T Shark, 2000.p.375.

11. Fayzieva R. Letters from the front // Saodat. 1985 .№5. p.9-10.

12. Awakened by Great October. Collection of essays and memoirs. -T .: 1961. p.248-249; Khujum means offensive. - $\mathrm{T}$.: Uzbekistan ,. 1987. -p42.

13. Andizhan regional state archive, fund 1 , list 3, case 3, pages 38-41; ARSA, 3rd fund, 88th list, 9th case, $23 \mathrm{rd}$ sheet.

14. Andizhan regional state archive, fund 18 , list 1 , case $5 a$, page 8 . 